\title{
Requintes de malvadez
}

"A menina matou o rato e está cheia de medo".

Dores

Na página 254 de Casas Pardas há um conto chamado "A Dama das Neves" onde se descreve, de modo não demasiado evidente, a maldade e o modo como esta pode ser prazerosa e ruim ao mesmo tempo, tornando-se, aos meus olhos, estas três páginas uma pedra-de-toque da obra de Maria Velho da Costa. Nelas, descreve-se a história do "grande demónio que vivia no mais alto pico da mais alta serrania da terra toda", dentro de um castelo com "lareiras de oiro e camas de minério de prata e pedras preciosas" e "manjares de boas carnes". O demónio, "que era da altura de três carros de milho", "vivia ensombrado de se ver assim sem mais companhia" e um dia pediu ao Grande Amo e Senhor das coisas brancas que lhe desse uma filha para que esta o pudesse acompanhar "neste tempo sem termo, nesta morada [...] dos sítios mais ermos e mais altos e mais frios de toda a terra". Na manhã seguinte, quando o grande demónio acorda vê que lhe está a nascer sobre o sítio do coração, dentro de um cristal de rocha, uma menina que ia crescendo. Quando, dias mais tarde, o grande demónio se atreve a tocar no cristal este desfaz-se em mil pedaços airosos que esvoaçam para o chão e a menina abre os olhos e diz: "Bom dia, Senhor Pai, dê-me a sua bênção".

O conto não se explica e por isso nunca chegamos a perceber porque não abandona o demónio as lareiras de oiro e as camas de minério de prata e pedras preciosas (note-se o plural em "camas", a acentuar a riqueza e a solidão do demónio), limitando-se a mudar do mais alto pico da mais alta serrania para um sítio onde houvesse mais gente. É igualmente estranho que alguém, que nunca sabemos quem é, faça a vontade a um demónio, dando-lhe nada mais nada menos do que uma filha. O facto de esta nascer do coração do demónio indica alguma esperança para uma vida a dois, mas o facto de as suas primeiras palavras ao pai serem "Bom dia, Senhor Pai, dê-me a sua bênção", implica certa subserviência perante o seu progenitor. Que tipo de bênção, perguntará o leitor, pode dar um demónio?

Em "A Dama das Neves", mal e bem existem em simultâneo, e o requinte da linguagem usada para descrever pormenores no texto serve para sublinhar aquilo a que geralmente chamamos malvadez. Neste texto, como noutros, desde a magna Missa in Albis a Myra, a sofisticação da linguagem é usada para descrever a forma como somos, todos, piores do que deveríamos, e como nos momentos em que estamos a ser ruins, pequenos e malvados, 
conseguimos ter actos de generosidade, compreensão e atenção para com outros. A linguagem usada por Maria Velho da Costa é a de Babel (expressão de António Guerreiro) porque a crueldade não se cinge a uma classe social específica, não pertence a um estrato económico ou a um género.

A complexidade da linguagem usada é transposta de romance para romance, tal como sucede com as personagens, a Elisa de Casas Pardas a surgir em Irene, ou Myra que, como a autora afirma numa entrevista, "é como uma Maina que fala". Nas suas várias obras, neste encadeamento de personagens, linguagens e por vezes outras vozes autorais (como sucede em Novas Cartas Portuguesas e em O Livro do Meio), Maria Velho da Costa faz-nos ver o positivo e negativo da maldade, como se nos levasse a observar os dois lados de uma moeda ao mesmo tempo e, ao fazê-lo, nos mostrasse que o juízo sobre o seu valor é por nós determinado.

Se se pensar na obra de Maria Velho da Costa a esta luz talvez se consigam reinterpretar temas como o feminismo, o colonialismo, entre outros, considerando-os subsecções de um problema maior, que é ilustrado na eventual resposta à crueldade do grande demónio (afinal, que há-de fazer a filha ou o Caliban que começa por pedir a bênção ao pai a não ser revoltar-se contra ele?). Existe, ainda, a crítica ao modo como nos decidimos, ou não, tornar família uns dos outros, sejam esses outros pessoas ou animais, como sucede no caso de Myra. Assim, com "A Dama das Neves" percebemos que a paternidade surge como resultado do desejo egoísta de companhia, uma crueldade que gera vidas (com graus variáveis de felicidade) todos os dias. É por isso que quando Madalena, preocupada, interrompe a história para perguntar se o Demónio morre, Elisa lhe responde que "não, minha querida, os demónios nunca morrem, coitados". Assim se compreende que "A Dama das Neves" é uma tragédia e que, se os demónios nunca morrem, é porque ficam connosco mais tempo do que deviam. Também é por isso que, em Dores, talvez não tenha sido a menina quem matou o rato, mas sim quem queria ver-se livre da criança. 